\title{
Effect of Tin Oxide/Black Paint Coating on Absorber Plate Temperature for Improved Solar Still Production: A Controlled Indoor and Outdoor Investigation
}

\author{
Sayfar Rasachak, ${ }^{1}$ Rana Sami Ullah Khan, ${ }^{2}$ Laveet Kumar, ${ }^{1}$ Taiba Zahid, ${ }^{3}$ \\ Usman Ghafoor $\mathbb{D}^{4}{ }^{4}$ Jeyraj Selvaraj, ${ }^{1}$ Rehena Nasrin $\mathbb{D}^{5},{ }^{5}$ and Muhammad Shakeel Ahmad ${ }^{1}$ \\ ${ }^{1}$ Higher Institution Centre of Excellence (HICoE), UM Power Energy Dedicated Advanced Centre (UMPEDAC), Level 4, \\ Wisma R\&D, University of Malaya, JalanPantai Baharu, 59990 Kuala Lumpur, Malaysia \\ ${ }^{2}$ Department of Mechatronics and Biomedical Engineering, Air University, Islamabad, Pakistan \\ ${ }^{3}$ NUST Business School, National University of Science and Technology, Islamabad, Pakistan \\ ${ }^{4}$ Department of Mechanical Engineering, Institute of Space Technology, Islamabad, Pakistan \\ ${ }^{5}$ Department of Mathematics, Faculty of Science, Bangladesh University of Engineering and Technology, Dhaka 1000, Bangladesh
}

Correspondence should be addressed to Rehena Nasrin; rehena@math.buet.ac.bd and Muhammad Shakeel Ahmad; shakeelalpha@gmail.com

Received 3 August 2021; Revised 27 September 2021; Accepted 4 December 2021; Published 22 January 2022

Academic Editor: Mamdouh El Haj Assad

Copyright (c) 2022 Sayfar Rasachak et al. This is an open access article distributed under the Creative Commons Attribution License, which permits unrestricted use, distribution, and reproduction in any medium, provided the original work is properly cited.

\begin{abstract}
The ever-increasing water stress and availability of fresh drinking water are becoming a major challenge in rural and urban communities. The current high-end and large-scale technologies are becoming way more expensive and not friendly to the environment. In this regard, solar still is becoming a prominent and promising future technology due to its environmentfriendly nature, less maintenance and operational costs, and simple design. The technological challenge regarding solar still is its low distillate yield. In this study, an attempt has been made to investigate the effect of tin oxide $\left(\mathrm{SnO}_{2}\right)$ on the absorption surface of solar still towards improvement in sunlight absorption, which would lead to high distillate production rates. Various concentrations of $\mathrm{SnO}_{2}$, i.e., $0.5 \mathrm{wt} \%, 1 \mathrm{wt} \%, 3 \mathrm{wt} \%, 5 \mathrm{wt} \%, 7 \mathrm{wt} \%, 10 \mathrm{wt} \%, 15 \mathrm{wt} \%$, and $20 \mathrm{wt} \%$, have been mixed in black and applied on the absorber plate to further optimize the suitable concentration. The experiments have been performed in both indoor (simulated) and outdoor conditions. An increase in surface temperature of absorber plate has been observed with increasing concentration of $\mathrm{SnO}_{2}$ under both the indoor and outdoor conditions, which is due to high solar spectrum absorption properties of $\mathrm{SnO}_{2}$ in the ultraviolet (UV) and near to far-infrared (IR) regions. The highest surface temperature of $101.61^{\circ} \mathrm{C}$ has been observed for specimens containing $15 \mathrm{wt} \% \mathrm{SnO}_{2}$ in black paint under indoor conditions at $1000 \mathrm{~W} / \mathrm{m}^{2}$ irradiation levels, which is $53.67 \%$ higher compared to bare aluminum plate and $16.91 \%$ higher compared to only black paint coated aluminum plate. On the other hand, the maximum temperature of $74.96^{\circ} \mathrm{C}$ has been recorded for the identical specimens containing $15 \mathrm{wt} \% \mathrm{SnO}_{2}$ under uncontrolled outdoor conditions. The recorded temperature is $47.96 \%$ higher than the bare aluminum plate and $14.88 \%$ higher than the black paint-coated aluminum plate. The difference of maximum temperatures under indoor and outdoor conditions is due to uncontrolled outdoor conditions and convective losses.
\end{abstract}

\section{Introduction}

Fresh drinking water is an essential need for human survival, and it plays a vital role in environmental sustainability. Due to the increase in population, the demand for fresh drinking water is also increasing. Even though the earth is $70 \%$ covered with water, $97 \%$ is saline water. Only $3 \%$ is remaining as freshwater, and out of this, $2 \%$ is inaccessible because of frozen icy masses [1]. Therefore, solar energy is a practical and feasible approach for properly utilizing seawater and 
producing freshwater out of it. Solar energy is becoming a key future energy source for various applications [2]. Solar desalination has been observed as the most feasible and cost-effective technique to produce fresh water at a lower cost than the other possible seawater desalination processes [3]. More precisely, the solar desalination method employing solar stills is the most viable method to supply fresh water in arid and remote areas [4]. The experimental study investigated the performance of an installed solar condensation device on the course of the antiseptic ultraviolet wastewater, which has wholly been evaluated in practical terms for the thermal output, conduction output, and production output of freshwater. The findings show the relative error rates of around $7.2 \%$ and $4.9 \%$ for day and night thermal outputs. In addition, relative mistakes in the driving efficiency were around $7 \%$ and $5.6 \%$ for day and night. On average, the thermal energy storage substratum's relative cumulative inaccuracy was around 3.5 percent daily in one month. Hence, laboratory and experimental data support the view that solar desalination systems work very well [5].

Solar still is a sealed box-like structure with a transparent glass top cover and structural decoration. The water inside the box is to be heated by direct sunlight. A transparent glass top cover that permits the infiltration of solar radiation and excites the evaporation. The water vapors in contact with the backside of the top glass cover become liquid and collected for various applications. Although the technique is straightforward and lucrative, it suffers low productivity per active square area. This is primarily because of the temperature variance between the cover and water in the basin which is responsible for heat transfer from transparent cover and the water in the basin. This heat transported causes a rise in the temperature of the cover [6]. Therefore, various authors have investigated the possible ways for increasing the productivity of solar stills. Experimentally, the performance of the solar desalination pond is examined for the generation of freshwater. The result shows that the sunlight intensity is the most crucial in the solar water desalination unit since the amount of freshwater generated is related to the solar's radiation intensity. In addition, the efficiency of the device is determined by elements such as environmental temperature, wind speed, and saltwater temperature. Experimental results also show that the salinity content of the wastewater heat storage area in the solar pond may be improved. The data collected demonstrate that a dense area can create saline content that contributes to increased temperature. Results show that salinity increases improve the condensation rate. Therefore, the brackish water might be increased in this situation. The mathematical conclusions also coincide exceptionally well with the empirical facts [7].

Moreover, the depth of basin water is one of the essential parameters in the evaporation rate and overall performance of solar still. An experimental study examined the effect of basin water depth on the performance of a single slope (SS) basin type solar still. In this study, the effect of saline water depth varying from 2 to $10 \mathrm{~cm}$ and salinity of water, which was $3000,50000,10000,150000$, and $20000 \mathrm{ppm}$ on yield, was carried out. The research resulted that the thermal efficiency drops with an increase in depth and salinity of basin water. The maximum efficiency was attained at a minimum water depth of $02 \mathrm{~cm}$ in the basin and produced the maximum distilled water [8]. Another researcher conducted an experiment on the performance of single slope (SS) solar still and double slope (DS) solar still by changing the depth of basin water at $1,2.5,5$, and $7.5 \mathrm{~cm}$. From the experimental results, it has been concluded that a decrease in water depth resulted in an increase in yield. The performance of DS solar still outweighed the SS solar still for the similar water depth [9]. Another experiment was conducted between the single basin double slope (SBDS) solar still and double basin double slope (DBDS) solar still using different depths vary from 1 to $5 \mathrm{~cm}$. It was observed that DBDS insulated still made $17.38 \%$ higher yield than SBDS insulated still at $1 \mathrm{~cm}$ depth of basin water. The results prove that DBDS solar still gave a higher performance than the SBDS solar still, and the depth of basin water has a considerable effect on the production rate of solar still [10]. The study has experimentally analyzed the effect of water depth in comparing the performance of pyramid solar still (PSS) and the single slope solar still [11]. The results concluded that reducing depth gives higher productivity, and PSS performs higher than SS solar because of its greater condensation area.

Another experiment has investigated an integrated solar pond with a forced circulation crystallizer (FCC). Several parameters have been observed, such as temperature gradient, evaporation rate, and density in a solar pond. The results show that the density of wastewater is decreased as the depth of wastewater increases because of salt diffusion. This demonstrates that height affects thermophysical properties. Hence, the highest thermal capacity is observed in the lowest layer. Moreover, a salt gradient is noticed because the brine is immobile in the pond, and the top layer gradually contains less salt than the lowest layer. As a result, the lowest layer's heat capacity increases during the procedure. A density differential prevents free convection in the layers. As a result, solar energy reaching the lowest layer is absorbed, resulting in a temperature differential in the layers. In the lowest layer, the rate of absorbed insolation is high.

The efficiency of thermal solar desalination methods such as distillers is enhanced by nanofluid [12]. Nanotechnology is possible to improve medium and process performance, reduce device sizes, and improve mechanical requirements. Because of their enhanced thermophysical characteristics, nanofluids are widely utilized in heat transfer media and energy systems. There are various forms of nanostructures relevant to the production of nanofluids as solid phases for dispersion in pure fluids. The use of these sorts of nanoparticles leads to a dramatic increase in thermal conductivity by metals' high efficient thermal conductivity [13]. The experimental study employed three nanoparticles in a heat pipe: $\mathrm{Ag}, \mathrm{CuO}$, and $\mathrm{Al}_{2} \mathrm{O}_{3}$ [14]. The results show that $\mathrm{Ag}$ nanoparticles had the most beneficial impact, implying the most significant reduction in temperature differential between the heat source and sink of the examined heat pipe. Another experimental study has employed Ag nanoparticles in heat pipes with mesh screens [15]. The results show that nanoparticle contributes to reducing thermal resistance and improves the system's thermal performance. Moreover, 
nanofluids can be used in a geothermal system for increasing the acquisition of thermal energy from reservoirs, which means an increase in the efficiency of the systems [16].

Similarly, Ag/water nanofluid has been applied in a flat plate collector [17]. The results show an increment of liquid output's temperature when the concentration of nanofluid increases, which contributes to enhancing in heat transfer. Another study applied multiwalled carbon nanotubes (MWCNT) in the PVT system and investigated the system's efficiency [18]. The results have proved that nanofluid led to an increase in thermal efficiency with a deviation of only $0.49 \%$, based on numerical and experimental results, respectively. The study investigated the effect of applying graphene oxide nanofluid on the thermal performance of pulsating heat pipes [19]. The obtained results showed that adding graphene oxide nanosheets to the base fluid can reduce the thermal resistance of PHP by more than $40 \%$ with a concentration of $0.25 \mathrm{~g} / \mathrm{L}$. In addition, an increase in concentration reduces the thermal efficiency of PHP, which is explained by an increase in the dynamic viscosity of the working fluid. For estimating the thermal conductivity of Ag/water, the group method of data handling (GMDH) and artificial neural networks (ANN) are used [20]. The model's input data were the size of nanomaterials, their concentration, and the temperature of nanofluids. According to the computed correlation coefficients, the GMDH model is more accurate than the correlation. Correlation coefficients were 0.9482 and 0.986 for the correlation and GMDH models, respectively. The most significant relative errors for the described methods were around $19 \%$ and $11 \%$, respectively. Therefore, both techniques are acceptable for estimating the thermal conductivity of the nanofluid based on the values determined for these two statistical criteria.

Nanotechnology is incredibly crucial for the enhancement of heat transfer rate. For most solar thermal applications (e.g., solar still, solar pond, and solar water heaters), the heat exchange between sunray and fluid is vital to use heat transfer fluid (HTF) as a heat storage medium. However, the conventional system, which uses passive convection and conduction, results in a lot of energy use. Moreover, PCM's lower thermal conductivity conveys the increase of heat transfer time for the storage materials, causing the poor TES system performance. To increase the rate of heat transfer, utilizing nanotechnology in PCM has been performed by several experimental and numerical studies for upgrading the PCM, which leads to enhancing PCM's capability and eliminating the main drawback of PCM [21]. In addition, the use of nanofluids further increases the rate of heat dissipation from the cell in the case of active cooling. Hence, it contributes to increasing the efficiency of the system [22].

One of the main parts that contribute a lot to solar still production efficiency is the base plate, which acts as a solar radiation absorber and provides vital water energy. Mainly, aluminum or copper plates coated with black paints have been used for maximum radiation absorption. In a recent study, $\mathrm{TiO} 2$ nanoparticles have been mixed with black paint and coated on the absorbed plate to increase the radiation absorption. A $1.5^{\circ} \mathrm{C}$ increase in water temperature has been reported for $\mathrm{TiO}_{2}$ modified black paint compared to bare black paint. This increase in temperature leads to a $6.1 \%$ increase in solar still distillate yield [8]. In another study, $\mathrm{ZnO}$ Nano particulates have been investigated as reinforcement to the absorber plate. The absorber temperature of $70^{\circ} \mathrm{C}$ has been reported when coated with nanotubularshaped $\mathrm{ZnO}$ particles/black paint compared to the $60-65^{\circ} \mathrm{C}$ temperature of the reference sample [9]. The comparison of solar still with $\mathrm{ZnO}$ nanoplates and typical solar basin showed a rise of $20 \%$ in evaporation rates [G].

Similarly, an experimental study has investigated the efficiency of traditional solar still and solar still with $\mathrm{ZnO}$ nanoplates. Results have proved that solar efficiency still with $\mathrm{ZnO}$ nano-plates has increased $17 \%$ higher than typical solar still, representing $7.78 \mathrm{kWh}$ energy saving [23]. Furthermore, various other nanomaterials such as carbon nanotubes and graphene have been employed to achieve maximum temperature [24]. Similarly, $\mathrm{CuO}$ with various concentrations from 10 to $40 \%$ range has also been considered a nanomaterial and added to the black paint of the solar still to augment the performance of solar still. Results proved that applying $\mathrm{CuO}$ nanoparticles increased the distillate by 16 and $25 \%$ compared to the traditional solar still at a concentration of 10 and $40 \%$, respectively [25]. Another experimental study investigated the fumed $\mathrm{SiO} 2$ nanoparticle in black paint at a wide-ranging concentration from 10 to $40 \%$ coated on the absorber plate of stepped type solar still for augmenting the freshwater yield. As a result, the average temperature of water and absorber has been increased by 10.2 and $12.3 \%$, respectively, by adding the optimum concentration of nanoparticles (20\%) with black paint. Results also concluded that the total production from the solar is enhanced by $27.2,34.2,18.3$, and $18.4 \%$ for $10,20,30$, and $40 \%$ concentrations of concentration, respectively, compared to that of ordinary black paint [26]. Similarly, one of the researcher groups designed and made up two similar solar stills with different paints, i.e., black and white. Results obtained with white paint solar still had a $6.8 \%$ upsurge in the solar still efficiency compared to the ordinary black paint [27].

Moreover, some authors suggested mixing various nanoparticles, i.e., $\mathrm{CuO}, \mathrm{Al}_{2} \mathrm{O}_{2}, \mathrm{TiO}_{2}$, and $\mathrm{Si}$, directly with water for the easiness of the process [28-30]. In one study, experimental comparisons were investigated between the solid nanoparticles of $\mathrm{CuO}$ and $\mathrm{Al}_{2} \mathrm{O}_{3}$ nanofluid and concluded that the nanoparticles enhanced the freshwater production by around $125.0 \%$ and $133.64 \%$, respectively [31]. Nevertheless, this approach (nanofluids) may contaminate the water due to its direct contact with water. Various other approaches for improved distillate yield include using wick materials such as cotton, wool, nylon, wood pulp paper, styrene sponge, and coral fleece. In addition, the shape modification of absorbed plate to improve contact surface area has been employed with promising results. Recently, our research group showed improved surface temperature using zinc microparticles in black paint [32].

Various modification performed in the solar still that are provided in the literature review. It is found that the efficiency can be augmented by various techniques, such as utilizing fins, PCM, heater, and mixed nanoparticles with saline water. However, it can be deduced that there are 


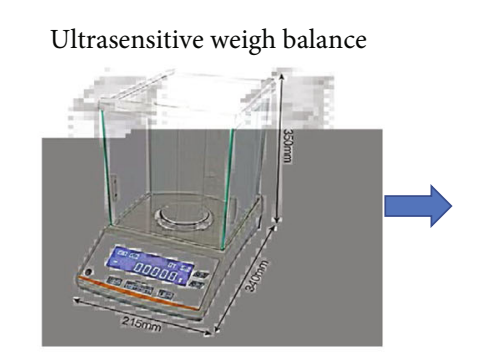

Hand mixing $\mathrm{SnO}_{2}$ nano-particles with isopropyl alcohol
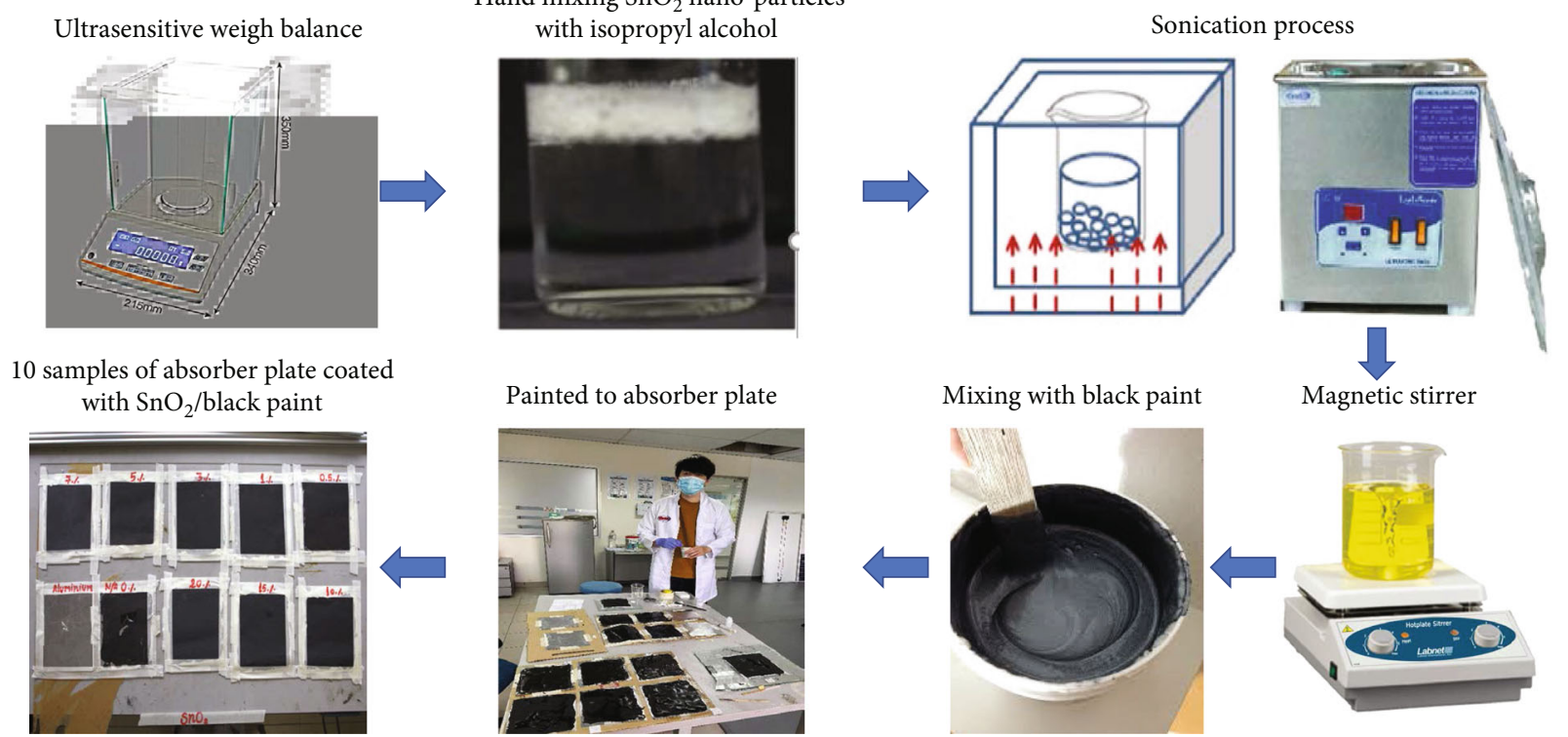

Painted to absorber plate

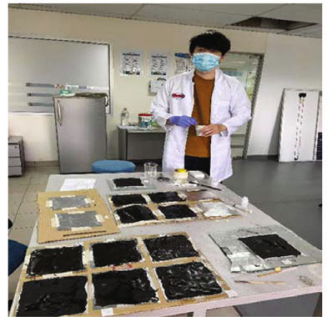

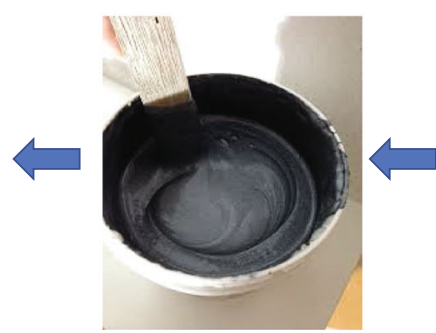

Magnetic stirrer

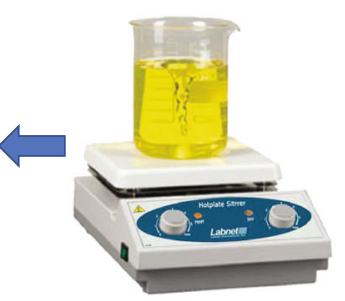

Figure 1: The process of impregnating $\mathrm{SnO} 2$ nanoparticles in absorber plates coated with black paint.

minimal studies carried out in solar still using nanoparticles in black paint. Herein, for the first time, this study presented a systematic investigation of the effect of and tin oxide particles/black paint composite as a highly effective absorber coating material. In this regard, we conducted a detailed indoor and outdoor investigation of variations in temperatures of the absorber plate concerning the size and concentration of $\mathrm{SnO}_{2}$ nanosized particles. As a result, a detailed and systematic investigation has been performed to understand the effect of the concentration and size of $\mathrm{SnO}_{2}$ nanoparticles. Furthermore, the experimental investigations under simulated indoor and outdoor conditions revealed indepth effects of the concentration and size of $\mathrm{SnO}_{2}$ nanoparticles.

\section{Experimental}

2.1. Material. Nanoparticles of tin oxide $\left(\mathrm{SnO}_{2}\right)$ were purchased from Sigma-Aldrich, and isopropyl alcohol $\left(\mathrm{CH}_{3} \mathrm{CHOHCH}_{3}\right)$ which is reagent grade was procured from Sigma-Aldrich. Black 0099 J paint was purchased from Korea Chemical Co., Ltd, Malaysia.

2.2. Fabrication Method. Figure 1 shows the schematic process diagram of specimen preparation. Black paint was considered base fluid to paint onto absorber plate and $\mathrm{SnO}_{2}$ nanoparticles in the various fractions $0.5,1,3,5,7$, 10,15 , and $20 \mathrm{wt} \%$ as nanofiller. In brief, the $\mathrm{SnO}_{2}$ nanoparticles were added to $5 \mathrm{~mL}$ of isopropyl alcohol, sonicated for 1 hour and half, and stirred over 1 hour to achieve proper inflation without incorporation. The as-readied suspension was blended in with $10 \mathrm{~mL}$ dark paint and hand-mixed tenderly. The prepared mixtures, i.e, black paint $/ \mathrm{SnO}_{2}$ nanoparticles have been painted to aluminum sheets using the paint brush and dried at room temperature last 24 hours. Figure 1 illustrates the sample preparation method.
2.3. Experimental Setup. Indoor setup has been carried out at solar thermal laboratory, UMPEDAC, University of Malaya. There are many components and instruments used in this experiment to fulfill the required indoor conditions. For providing required irradiations, a solar simulator comprising 120 halogen bulbs (Brand: OSRAM) with power, voltage, and current capacity of $90 \mathrm{~W}, 12 \mathrm{~V}$, and $7.5 \mathrm{~A}$, respectively, is used. The solar simulator is controlled by three variable control AC-power-supply transformers which can simulate the solar radiations from $100 \mathrm{~W} / \mathrm{m}^{2}$ to $1200 \mathrm{~W} / \mathrm{m}^{2}$. Further, few other standard measuring instruments are used to record the data. Some essential instrumentation and sensors used are pyranometer (Brand: LI-COR, LI200R)), data logger (Brand: Data taker (DT80)), and thermocouples (Ktype). The measuring and accuracy range of all the instruments and sensors is given in Table 1.

For the indoor experiment procedure, the samples of size $6^{\prime \prime} \times 6^{\prime \prime}$ were placed on a cardboard in the solar simulator. The eight (08) samples with different concentrations of silicon (Si) nanoparticle-coated plates, one (01) black paint coated plate, and one (01) bare aluminum plate were placed in two rows with a displacement of 3 inches apart on the cardboard. The $K$-type thermocouple was placed on each plate and the pyranometer in the center to record the change in temperature and varying radiations. Experiments were conducted in indoor working conditions with varying radiations from $100 \mathrm{~W} / \mathrm{m}^{2}$ to $1000 \mathrm{~W} / \mathrm{m}^{2}$ using a solar simulator. It was observed that it took about 30 minutes in each irradiation level of an experiment to reach the stable conditions, and then the solar simulator was switched off for about 15 minutes to record the decreasing temperature of all plates. The schematic and actual arrangement of the indoor experiment is depicted in Figures 2(a) and 2(b), respectively.

The outdoor experimental setup has been installed on Level 3 (Solar Garden) of Higher Institution Centre of Excellence, UM Power Energy Dedicated Advanced Centre 
TABLE 1: Measuring ranges and accuracy.

\begin{tabular}{lccc}
\hline Instrument & Range & Accuracy & Instrument \\
\hline Pyranometer (model: LI-COR, LI200R) & 0 to $2000 \mathrm{~W} / \mathrm{m}^{2}$ & $\pm 5 \%$ & Pyranometer (model: LI-COR, LI200R) \\
Data logger (model: data taker DT80) & -270 to $1372^{\circ} \mathrm{C}$ & $\pm 2 \%$ & Data logger (model: data taker DT80) \\
Thermocouple (K-type) & -200 to $1000^{\circ} \mathrm{C}$ & $\pm 1.5^{\circ} \mathrm{C}$ & Thermocouple $(K$-type) \\
\hline
\end{tabular}

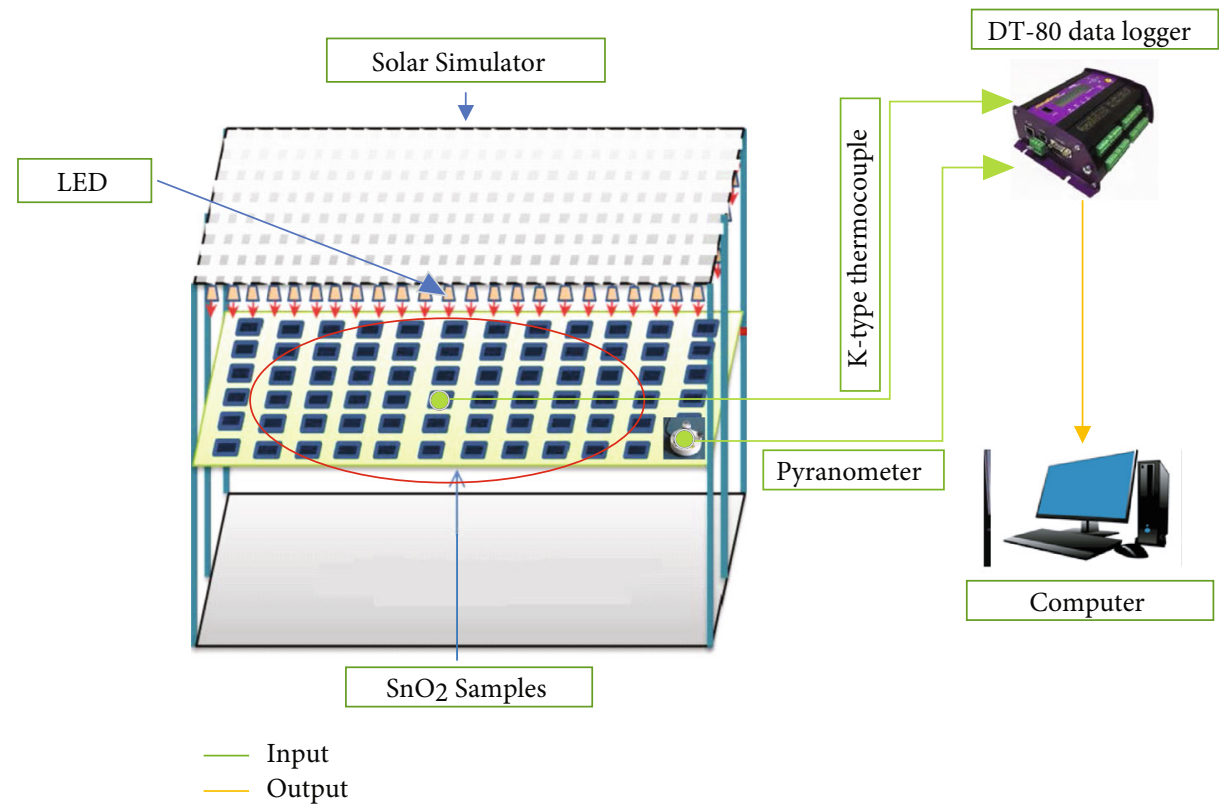

(a)

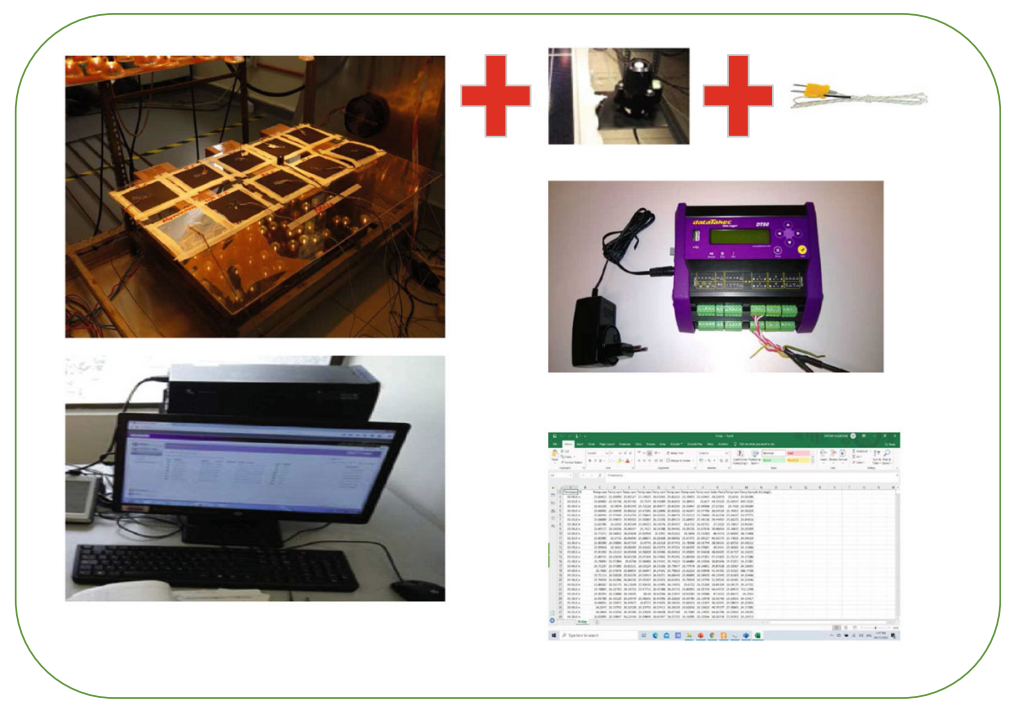

(b)

Figure 2: (a) Schematic of Indoor experimental setup and (b) actual Indoor experimental setup.

(UMPEDAC), Kuala Lumpur, Malaysia. Experiments were carried out from 8.00 am to $05: 00 \mathrm{pm}$. Same standard devices and instruments were used to record the data, and the measuring and accuracy range of all the instruments and sensors is already given in Table 1 . Sensors were placed to the systems at the necessary locations for recording the data. In addition, other meteorological data such as wind speed were measured using the weather station installed at Solar Garden. 

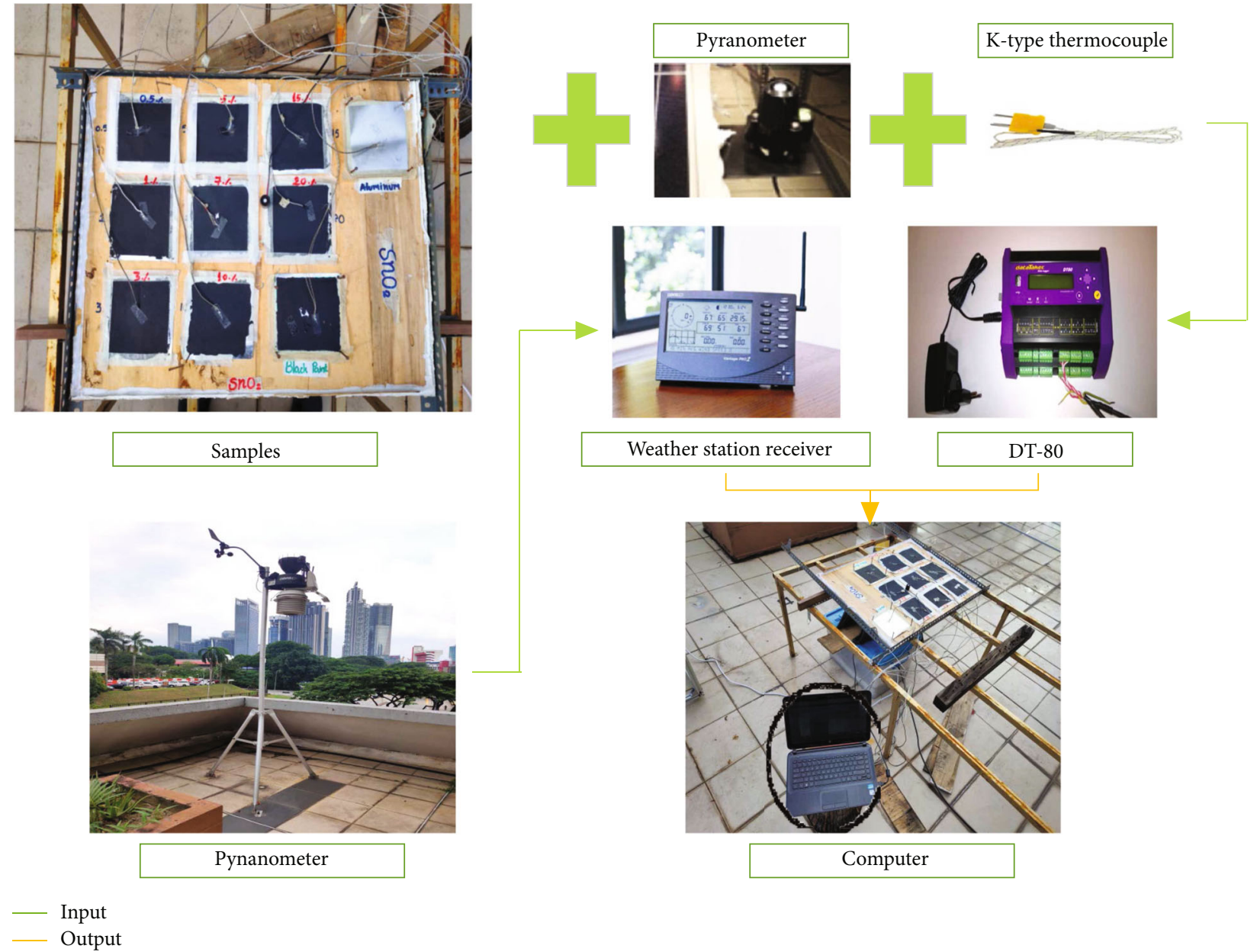

FIGURE 3: Outdoor experimental setup.

The same arrangement of samples, i.e., silicon-coated nanoparticles, the plate coated with black paint, and the aluminum plate attached, were attached to a wooden sheet of a thickness of $1^{\prime \prime}$ was mounted at an optimum inclined angle of 15 degrees. The layout of the outdoor experiment, including the position and connectivity of all instruments and components, is systematically represented in Figure 3. The optimum angle was calculated using Cooper's equation (1) to intercept the maximum radiations throughout the day. Note that the experiment has been performed for seven days from $8: 00$ am to $5: 00 \mathrm{pm}$, and only the best data with maximum sun hours has been presented here.

$$
\delta=23.45 \sin \left[0.9863\left(284+n_{1}\right)\right]
$$

where $\delta$ is the inclination angle, and $n_{1}$ is the day of the year.

2.4. Characterization. The morphological and compositional analyses were conducted by using scanning electron microscopy (SEM) (Tescon Mira) in secondary electron mode and $\mathrm{X}$-ray diffraction (XRD), respectively. Further, the Uv-vis spectroscopy has been used to identify the absorption in the electromagnetic spectrum.

\section{Result and Discussion}

Figure 4 shows the scanning electron micrographs (SEM) along with X-ray diffraction (XRD) and UV-visible spectroscopy to understand surface morphology, composition, and light absorption characteristics of as received $\mathrm{Zn}$ particles. The particle size mentioned by the suppliers is in the range of $18-20 \mathrm{~nm}$, and the shape is almost spherical. Figure 4(b) shows the XRD pattern of the as-received $\mathrm{SnO} 2$ particles with miller indices. The diffraction is in agreement with JCPDS number 41-1445 for confirmation [11]. Figure 4(c) shows the UV-vis spectra of as received particles. First, a sharp absorption in the UV region has been identified, followed by a reduction in absorption. The second absorption has been identified in the near-infrared region with an onset starting after $1000 \mathrm{~nm}$ of the solar spectrum. This high absorption in UV and near-infrared region indicates high sunlight absorption properties which helped improve the surface temperature of the absorber plate.

3.1. Global Irradiation and Wind Pattern. Figure 5 shows the variation of ambient temperatures, relative humidity, wind speed and direction, precipitation, and cloud cover across the year from December 2019 to 2020 . It can be seen that 


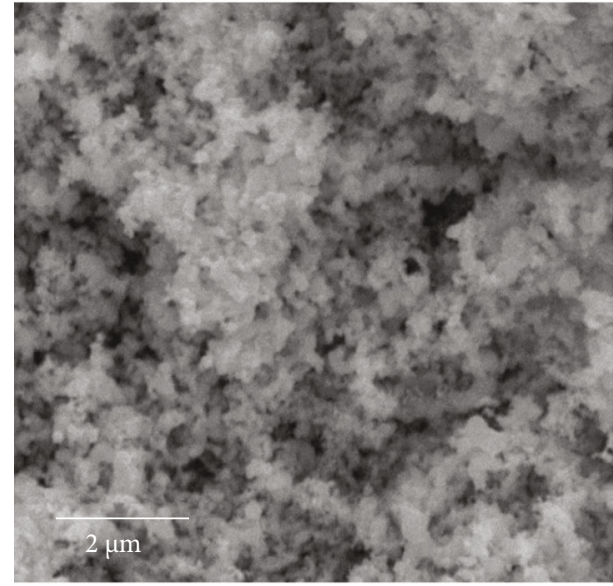

(a)

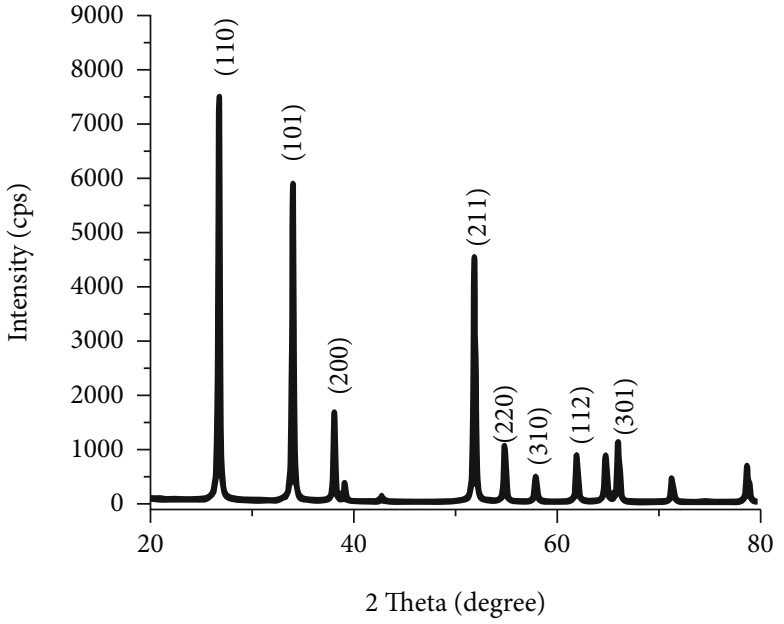

(b)

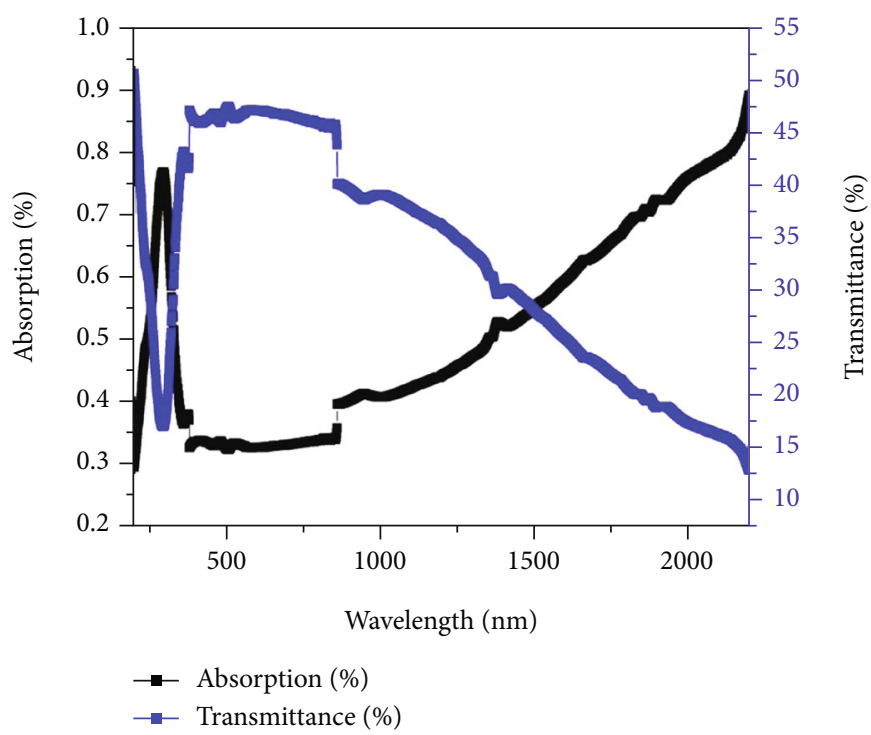

(c)

Figure 4: (a) SEM, (b) XRD, and (c) Uv-vis spectra of as received nanopowder.

the profile is almost consistent within an average of $25^{\circ} \mathrm{C}$ throughout the year. However, maximum and minimum temperature of $34^{\circ} \mathrm{C}$ and $23^{\circ} \mathrm{C}$ is also seen in March [33].

3.2. Indoor Testing. The variation in temperature operated in this present investigation is depended on the solar irradiance level and effect of different concentrations of $\mathrm{SnO}_{2}$ particles. Figure 4 shows the result of an indoor experiment under irradiation of $200,400,800$, and $1000 \mathrm{~W} / \mathrm{m}^{2}$. Moreover, the summary of indoor experimental tests at $1000 \mathrm{~W} / \mathrm{m}^{2}$ irradiation level has been presented in Table 2 .

An increase in surface temperature has been observed with an increment in nanoparticles concentration, as shown in Figure 6(A1). The highest temperature has been exhibited by specimens containing $15 \mathrm{wt} \% \mathrm{SnO}_{2}$ nanoparticles. Further increase in concentration did not increase the surface temperature. The rate of temperature drop has also been measured and presented in Figure 6(B1). A slow rate of temperature loss has been observed in the case of specimens containing $3 \mathrm{wt} \% \mathrm{SnO}_{2}$ followed by $5 \mathrm{wt} \%$ and $7 \mathrm{wt} \%$. In contrast, the specimen showing the highest increase in temperature (i.e., $15 \mathrm{wt} \% \mathrm{SnO}_{2}$ ) tends to drop temperature faster when cooled down. The same trend has been observed for all the irradiation levels.

A maximum rise in temperature of $101.81^{\circ} \mathrm{C}$ has been measured for specimens containing $15 \mathrm{wt} \% \mathrm{SnO}_{2}$ at $1000 \mathrm{~W} / \mathrm{m}^{2}$ irradiation level (Figure 6(D1)), which is much higher compared to the bare aluminum plate, i.e., $66.25^{\circ} \mathrm{C}$ and only black paint coated aluminum plate, i.e., $87.08^{\circ} \mathrm{C}$. Furthermore, the energy dissipation trend is also the same as measured at the $200 \mathrm{~W} / \mathrm{m}^{2}$ irradiation level. Further increase in concentration leads to a reduction in temperature, which can be explained based on the increased thermal conductivity of the specimen. At much higher concentrations, the temperature loss/heat dissipation rate is much higher, as shown in Figure 6(d2), which caused increased energy dissipation due to convection. The optimum concentration representing a high rise in temperature and optimum 

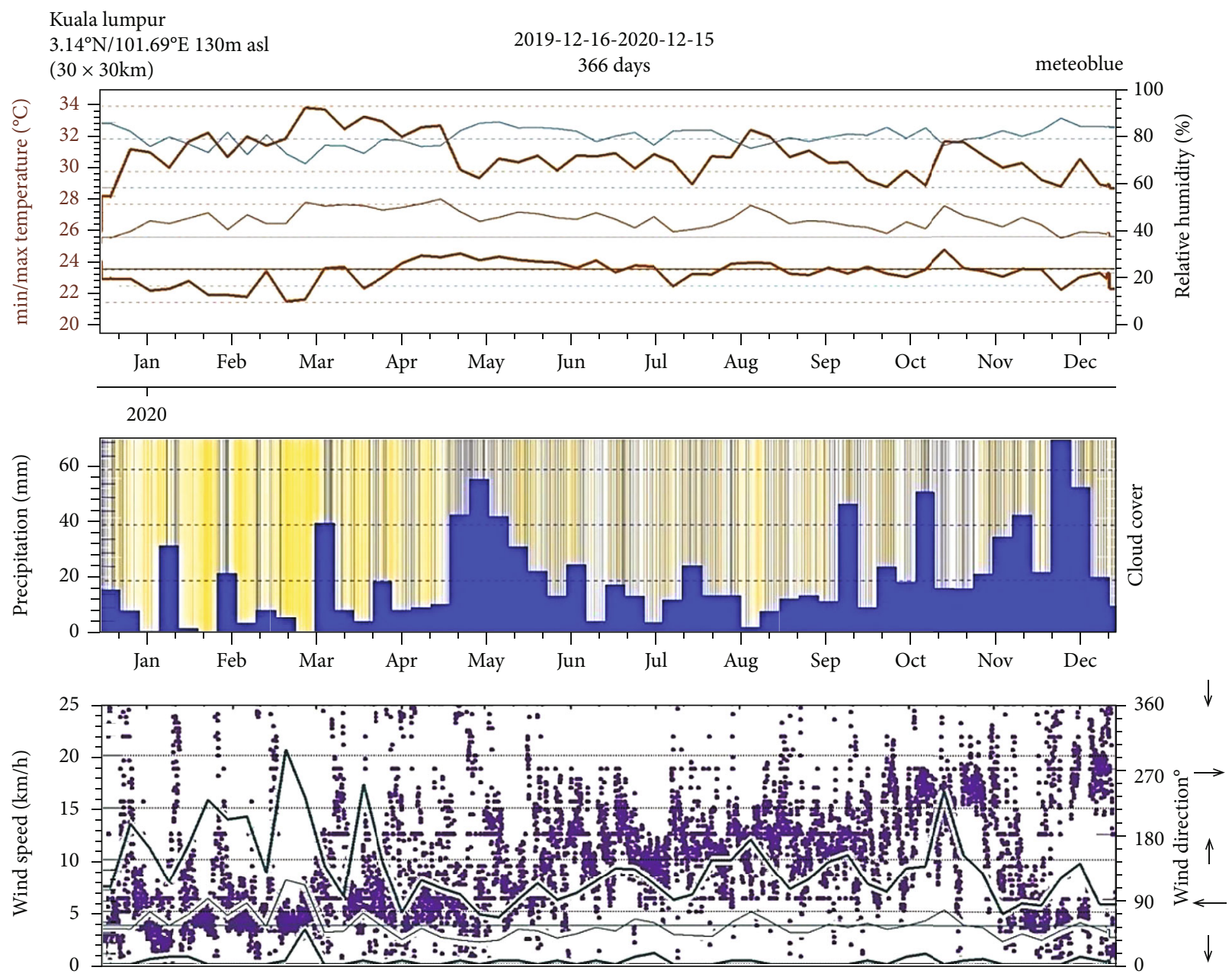

FIgURE 5: One-year weather data of Kuala Lumpur [33].

TABle 2: Maximum temperature attained at $1000 \mathrm{~W} / \mathrm{m} 2$ radiation level.

\begin{tabular}{lccc}
\hline Sr. no. & Matrix material & $\mathrm{SnO}_{2} \mathrm{wt} \%$ & Temperature ${ }^{\circ} \mathrm{C}$ \\
\hline 1 & & Aluminum sheet & 66.25 \\
2 & Black paint & 0 & 87.08 \\
3 & Black paint & 0.5 & 89.69 \\
4 & Black paint & 1 & 91.88 \\
5 & Black paint & 3 & 94.78 \\
6 & Black paint & 5 & 96.85 \\
7 & Black paint & 7 & 96.87 \\
8 & Black paint & 10 & 96.92 \\
9 & Black paint & 15 & 101.81 \\
10 & Black paint & 20 & 96.95 \\
\hline
\end{tabular}

convective energy dissipation was observed to be $15 \mathrm{wt} \%$ $\mathrm{SnO}_{2}$ in black paint for indoor tests.

3.3. Outdoor Testing. The outdoor experiments have been conducted using same equipment and sensors as mentioned in the experimental section at solar garden level
3, UMPEDAC, Wisma R\&D, Kuala Lumpur. The tests have been conducted from 08:00 am to 05:00 pm for whole week, and the result of highest sunshine day has been presented here along with the solar irradiation and wind speed of that particular day.

Figure 7 shows the temperature profile of the specimens along with the solar irradiation level and wind speed. The summary of the maximum achieved temperature for each specimen has been presented in Table 3. The highest surface temperature of $74.96^{\circ} \mathrm{C}$ has been recorded for specimens containing $15 \mathrm{wt} \% \quad \mathrm{SnO}_{2}$ nanoparticles, which is much higher than bare aluminum plate and only black paint coated aluminum plate, i.e., $50.80 \mathrm{oC} 65.25^{\circ} \mathrm{C}$, respectively. The second-highest temperature of $74.31^{\circ} \mathrm{C}$ has been recorded for the specimens containing $3 \mathrm{wt} \% \mathrm{SnO}_{2}$ nanoparticles, which is almost equal to that of specimen containing $15 \mathrm{wt} \% \mathrm{SnO}_{2}$. This is due to low convective energy dissipation, and the results are in high agreement with indoor results for optimum rate of temperature loss. However, the temperature is reduced for the specimen containing $20 \mathrm{wt} \%$ $\mathrm{SnO}_{2}$ because the further increase in concentration increased thermal conduction which in turn caused excessive heat losses due to convection. 

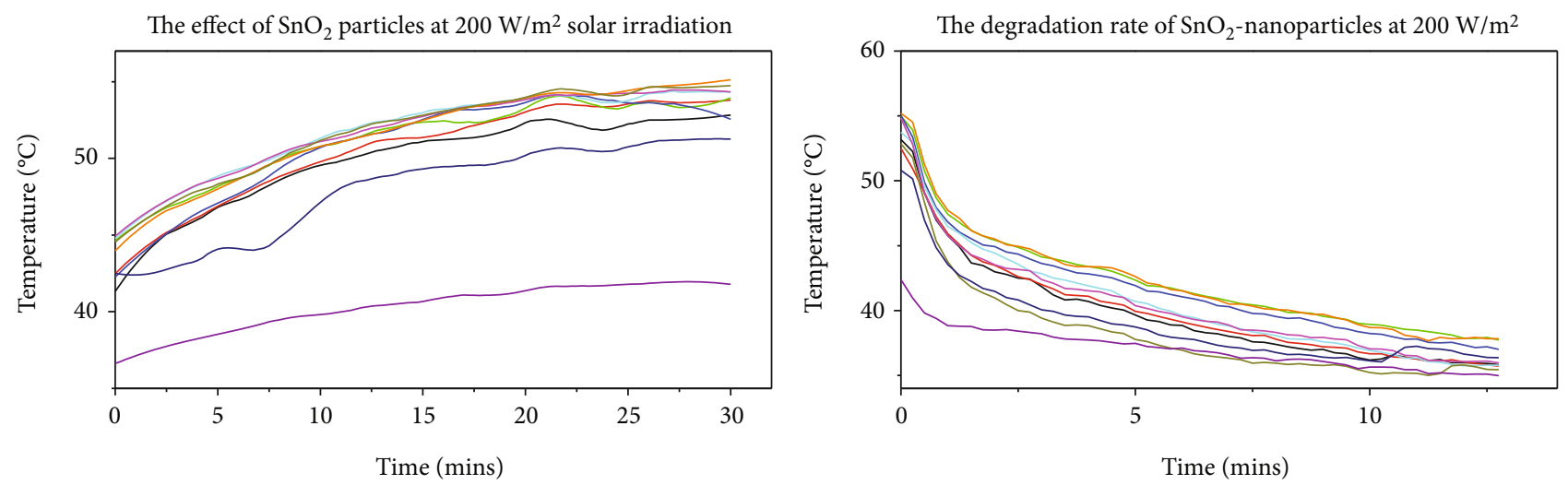

(a)
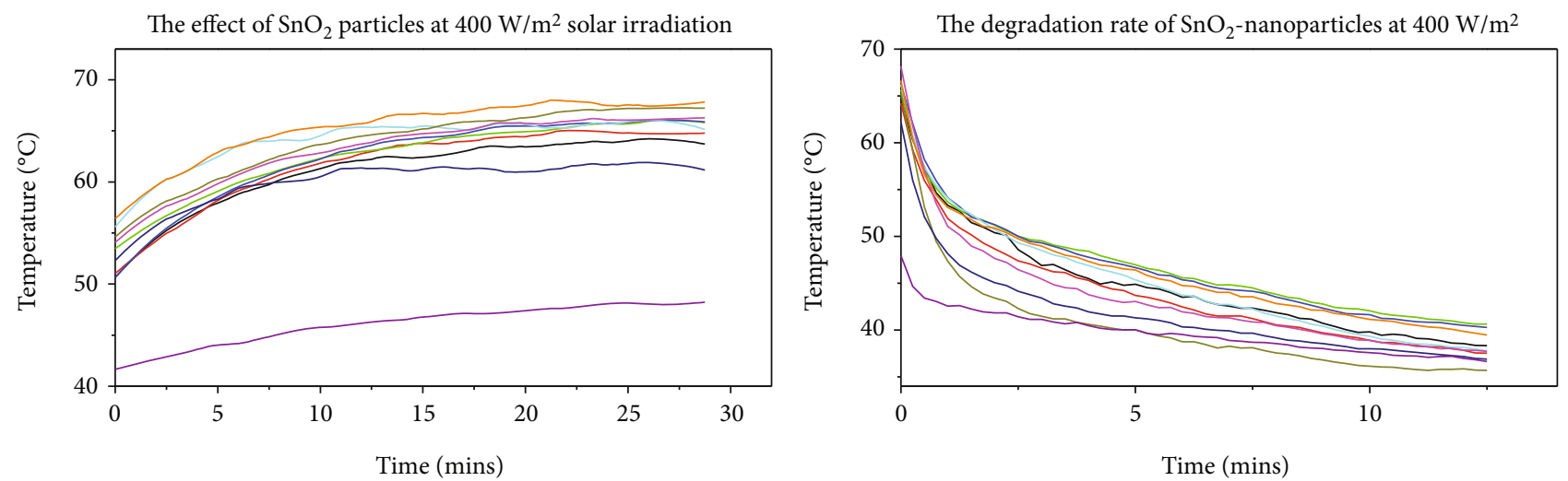

(b)
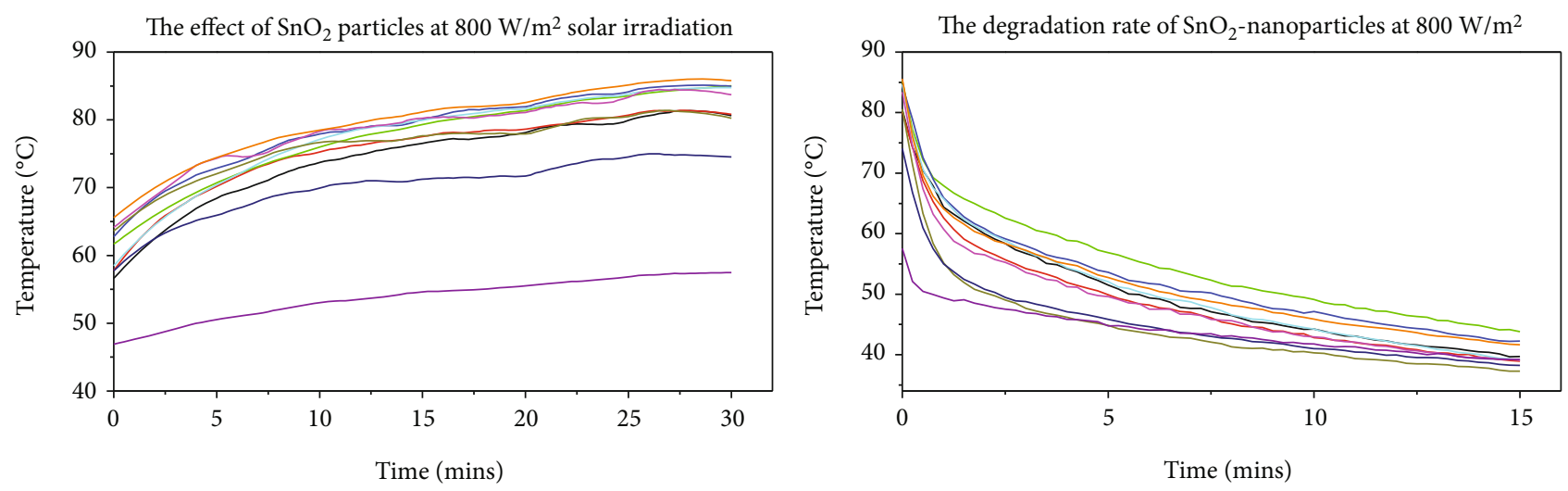

(c)

FIgURE 6: Continued. 

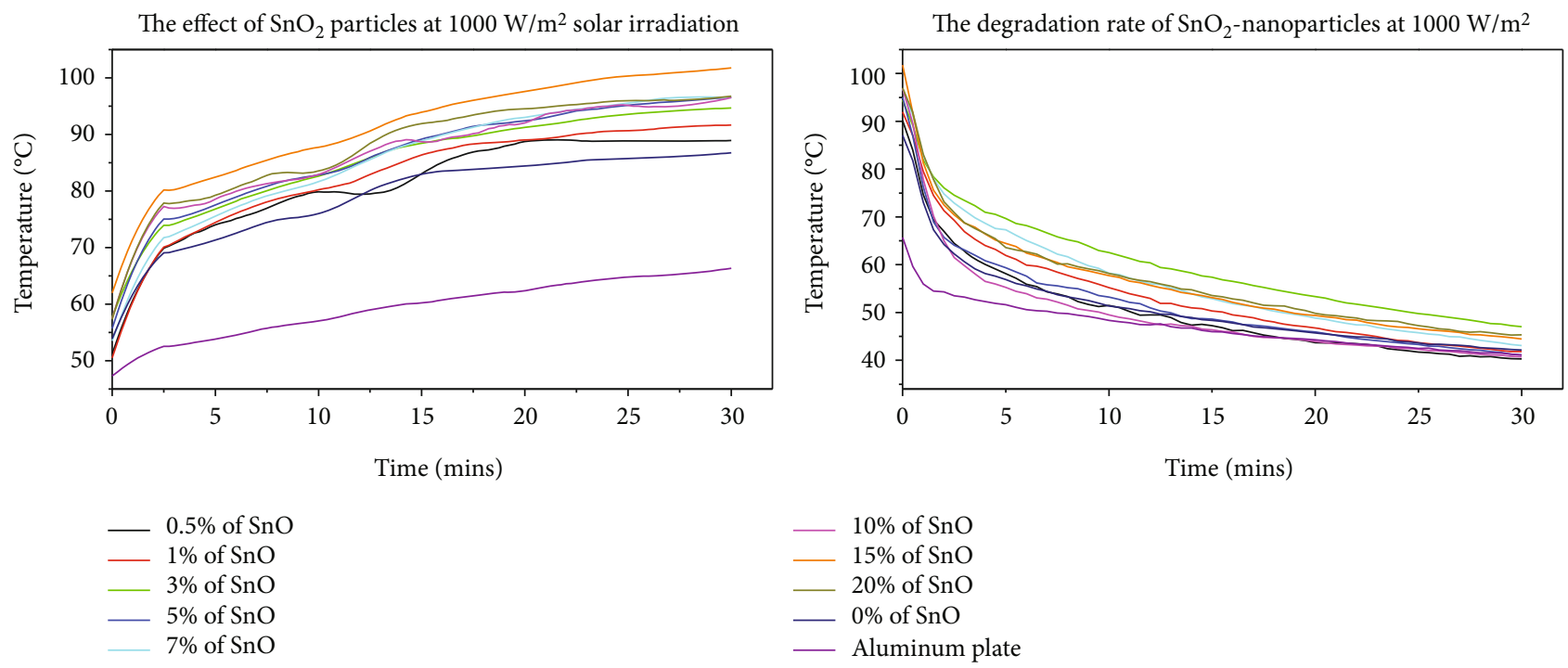

(d)

Figure 6: Effect on absorber temperature at irradiation exposure of (a) $200 \mathrm{~W} / \mathrm{m}^{2}$, (b) $400 \mathrm{~W} / \mathrm{m}^{2}$, (c) $800 \mathrm{~W} / \mathrm{m}^{2}$, and (d) $1000 \mathrm{~W} / \mathrm{m}^{2}$, and temperature-drop profile ( $\mathrm{Ai}, \mathrm{Bi}, \mathrm{Ci}$, and $\mathrm{Di})$.

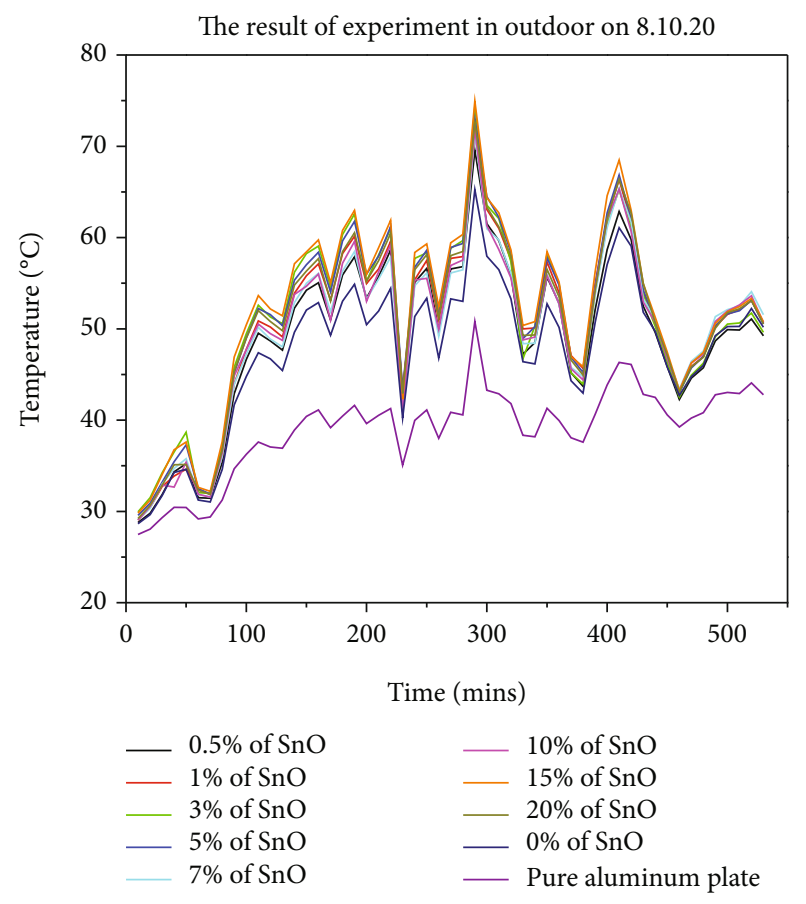

(a)

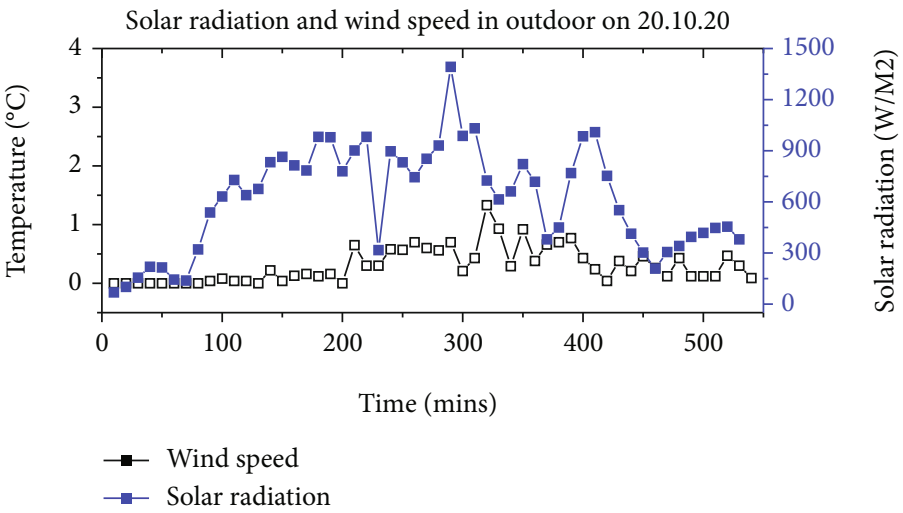

Figure 7: The various concentration effects on the sample's temperature in outdoor conditions was taken on 8.10.20. 
TABLE 3: Summary of outdoor experimental results.

\begin{tabular}{lccc}
\hline Sr. no. & $\begin{array}{c}\text { Matrix } \\
\text { material }\end{array}$ & $\mathrm{SnO}_{2} \mathrm{wt} \%$ & Max. temperature $\left({ }^{\circ} \mathrm{C}\right)$ \\
\hline 1 & & $\begin{array}{c}\text { Aluminum } \\
\text { sheet }\end{array}$ & 50.80 \\
2 & Black paint & 0 & 65.25 \\
3 & Black paint & 0.5 & 69.55 \\
4 & Black paint & 1 & 71.33 \\
5 & Black paint & 3 & 74.31 \\
6 & Black paint & 5 & 73.00 \\
7 & Black paint & 7 & 71.85 \\
8 & Black paint & 10 & 71.85 \\
9 & Black paint & 15 & 74.96 \\
10 & Black paint & 20 & 72.62 \\
\hline
\end{tabular}

\section{Conclusion}

The technology of solar still is improving at an incredible pace to avoid future scarcity of fresh drinking water. In this study, $\mathrm{SnO}_{2}$ nanoparticles have been investigated in an attempt to increase the sunlight absorption of the solar still absorber plate. Various concentrations of silicon particles have been mixed with black paint and applied to the absorber plate. SEM and XRD have been employed to examine surface morphology and composition, respectively. Uvvis spectroscopy has been conducted to study the optical absorption properties of silicon. Indoor and outdoor tests have been conducted using improvised apparatus. With the introduction of Si particles in black paint, the temperature rise has been observed, which can be associated with the ability of silicon to absorb sunlight in Uv and the visible range of the solar spectrum. The highest temperature of $101.81^{\circ} \mathrm{C}$ has been recorded for samples containing $15 \mathrm{wt} \%$ $\mathrm{SnO} 2$ in indoor conditions at $1000 \mathrm{w} / \mathrm{m}^{2}$ irradiation levels. The same samples with $15 \mathrm{wt} \%$ and $3 \mathrm{wt} \% \mathrm{SnO} 2$ performed the best in outdoor conditions, achieving $74.96^{\circ} \mathrm{C}$ and $74.31^{\circ} \mathrm{C}$ temperature, respectively. Further increment in concentration did not effectively improve the absorption characteristics due to the high convective energy loss rate caused by an excessive increase in thermal conductivity.

\section{Abbreviations}

ANN: $\quad$ Artificial neural networks

DS: $\quad$ Double slope

DBDS: Double basin double slope

ED: $\quad$ Electrodialysis

FCC: $\quad$ Forced circulation crystallizer

GMDH: Group method of data handling

HTF: Heat transfer fluid

IR: Infrared

MED: $\quad$ Multiple-effect distillation

MSF: $\quad$ Multistage flash distillation

MWCNT: Multiwalled carbon nanotubes

PCM: $\quad$ Phase change material

PVT: Photovoltaic thermal collector
PSS: $\quad$ Pyramid solar still

RO: Reverse osmosis

SBDS: $\quad$ Single basin double slope

SS: $\quad$ Single slope

SEM: $\quad$ Scanning electron microscopy

TES: Thermal energy storage

UV: $\quad$ Ultraviolet

XRD: X-ray diffraction.

\section{Data Availability}

The data used to support the findings of this study are available from the corresponding author(s) upon request.

\section{Conflicts of Interest}

The authors declare that they have no conflicts of interest.

\section{Authors' Contributions}

Sayfar Rasachak, Rana Sami Ullah Khan, and Laveet Kumar contributed equally to this work as first author.

\section{Acknowledgments}

The authors would like to acknowledge the financial assistance of Japan International Cooperation Agency for AUN/SEED-Net on Collaboration Education Program UM CEP 1901, Japan ASEAN Collaborative Education Program (JACEP). The authors would also like to thank the technical and financial assistance of UM Power Energy Dedicated Advanced Centre (UMPEDAC) and the Higher Institution Centre of Excellence (HICoE) Program Research Grant, UMPEDAC - 2020 (MOHE HICOE - UMPEDAC), Ministry of Education Malaysia, TOP100 UMPEDAC, RU0032020, University of Malaya.

\section{References}

[1] A. K. Biswas and C. Tortajada, Water Crisis and Water Wars: Myths and Realities, Taylor \& Francis, 2019.

[2] H. Samneang, L. Kumar, A. Zafar et al., "A systematic indoor and outdoor study of the effect of particle size and concentration of TiO2 in improving solar absorption for solar still application," Frontiers in Materials, vol. 8, article 683490, 2021.

[3] S. Liu, Z. Wang, M. Han, G. Wang, T. Hayat, and G. Chen, "Energy-water nexus in seawater desalination project: a typical water production system in China," Journal of Cleaner Production, vol. 279, article 123412, 2021.

[4] F. Liu, L. Wang, R. Bradley, B. Zhao, and W. Wu, "Highly efficient solar seawater desalination with environmentally friendly hierarchical porous carbons derived from halogencontaining polymers," RSC Advances, vol. 9, no. 50, pp. 29414-29423, 2019.

[5] M. Taherizadeh, F. Farahbod, and A. Ilkhani, "Experimental evaluation of solar still efficiencies as a basic step in treatment of wastewater," Heat Transfer-Asian Research, vol. 49, no. 1, pp. 236-248, 2020.

[6] M. S. S. Abujazar, S. Fatihah, and A. Kabeel, "Seawater desalination using inclined stepped solar still with copper trays in a 
wet tropical climate," Desalination, vol. 423, pp. 141-148, 2017.

[7] K. Srithar and T. Rajaseenivasan, "Recent fresh water augmentation techniques in solar still and $\mathrm{HDH}$ desalination - A review," Renewable and Sustainable Energy Reviews., vol. 82, pp. 629-644, 2018.

[8] A. Kabeel, R. Sathyamurthy, S. W. Sharshir et al., "Effect of water depth on a novel absorber plate of pyramid solar still coated with $\mathrm{TiO}_{2}$ nano black paint," Journal of Cleaner Production, vol. 213, pp. 185-191, 2019.

[9] S. M. Saleh, A. M. Soliman, M. A. Sharaf, V. Kale, and B. Gadgil, "Influence of solvent in the synthesis of nanostructured $\mathrm{ZnO}$ by hydrothermal method and their application in solar-still," Journal of Environmental Chemical Engineering, vol. 5, no. 1, pp. 1219-1226, 2017.

[10] N. Abdelal and Y. Taamneh, "Enhancement of pyramid solar still productivity using absorber plates made of carbon fiber/ CNT-modified epoxy composites," Desalination, vol. 419, pp. 117-124, 2017.

[11] M. A. Abdelkareem, M. el Haj Assad, E. T. Sayed, and B. Soudan, "Recent progress in the use of renewable energy sources to power water desalination plants," Desalination, vol. 435, pp. 97-113, 2018.

[12] M. Ramezanizadeh and M. Alhuyi Nazari, "Modeling thermal conductivity of ag/water nanofluid by applying a mathematical correlation and artificial neural network," International Journal of Low-Carbon Technologies, vol. 14, no. 4, pp. 468-474, 2019.

[13] H. Kavusi and D. Toghraie, "A comprehensive study of the performance of a heat pipe by using of various nanofluids," Advanced Powder Technology, vol. 28, no. 11, pp. 3074-3084, 2017.

[14] M. Ghanbarpour, N. Nikkam, R. Khodabandeh, and M. S. Toprak, "Thermal performance of inclined screen mesh heat pipes using silver nanofluids," International Communications in Heat and Mass Transfer, vol. 67, pp. 14-20, 2015.

[15] D. Sui, V. H. Langåker, and Z. Yu, "Investigation of Thermophysical properties of Nanofluids for application in geothermal energy," Energy Procedia, vol. 105, pp. 5055-5060, 2017.

[16] A. M. Tomy, N. Ahammed, M. S. P. Subathra, and L. G. Asirvatham, "Analysing the performance of a flat plate solar collector with silver/water nanofluid using artificial neural network," Procedia Computer Science, vol. 93, pp. 33-40, 2016.

[17] H. Fayaz, R. Nasrin, N. A. Rahim, and M. Hasanuzzaman, "Energy and exergy analysis of the PVT system: effect of nanofluid flow rate," Solar Energy, vol. 169, pp. 217-230, 2018.

[18] M. A. Nazari, R. Ghasempour, M. H. Ahmadi, G. Heydarian, and M. B. Shafii, "Experimental investigation of graphene oxide nanofluid on heat transfer enhancement of pulsating heat pipe," International Communications in Heat and Mass Transfer, vol. 91, pp. 90-94, 2018.

[19] K. Y. Leong, M. R. Abdul Rahman, and B. A. Gurunathan, "Nano-enhanced phase change materials: a review of thermo-physical properties, applications and challenges," Journal of Energy Storage, vol. 21, pp. 18-31, 2019.

[20] A. Maleki, A. Haghighi, M. el Haj Assad, I. Mahariq, and M. Alhuyi Nazari, "A review on the approaches employed for cooling PV cells,” Solar Energy, vol. 209, pp. 170-185, 2020.
[21] M. Jadidoleslami and F. Farahbod, "Experimental and mathematical evaluation of solar powered still equipped by nano plate as the principle stage of zero discharge desalination process," Advances in Energy Research, vol. 4, no. 2, pp. 147-161, 2016.

[22] E. J. N. Baticados, S. C. Capareda, S. Liu, and M. Akbulut, "Advanced solar still development: improving distilled water recovery and purity via graphene-enhanced surface modifiers. Frontiers in environmental," Frontiers in Environmental Science, vol. 8, article 531049, 2020.

[23] A. Kabeel, Z. M. Omara, F. Essa, A. Abdullah, T. Arunkumar, and R. Sathyamurthy, "Augmentation of a solar still distillate yield via absorber plate coated with black nanoparticles," Alexandria Engineering Journal, vol. 56, no. 4, pp. 433-438, 2017.

[24] R. Sathyamurthy, A. E. Kabeel, M. Balasubramanian, M. Devarajan, S. W. Sharshir, and A. M. Manokar, "Experimental study on enhancing the yield from stepped solar still coated using fumed silica nanoparticle in black paint," Materials Letters, vol. 272, article 127873, 2020.

[25] C. Tenthani, A. Madhlopa, and C. Kimambo, Improved Solar Still for Water Purification, DSpace software, 2012.

[26] K. V. Modi, H. K. Jani, and I. D. Gamit, "Impact of orientation and water depth on productivity of single-basin dual-slope solar still with $\mathrm{Al} 2 \mathrm{O} 3$ and $\mathrm{CuO}$ nanoparticles," Journal of Thermal Analysis and Calorimetry, vol. 143, no. 2, pp. 899913, 2021.

[27] H. Fayaz, M. S. Ahmad, A. K. Pandey, N. A. Rahim, and V. V. Tyagi, "A novel nanodiamond/zinc nanocomposite as potential counter electrode for flexible dye sensitized solar cell," Solar Energy, vol. 197, pp. 1-5, 2020.

[28] A. Kabeel, Z. Omara, and F. Essa, "Improving the performance of solar still by using nanofluids and providing vacuum," Energy Conversion and Management, vol. 86, pp. 268-274, 2014.

[29] M. S. Ahmad, S. S. Han, A. Zafar et al., "Indoor and outdoor performance study of metallic zinc particles in black paint to improve solar absorption for solar still application," Coatings, vol. 11, no. 5, p. 536, 2021.

[30] S. S. Han, U. Ghafoor, T. Saeed et al., "Silicon particles/black paint coating for performance enhancement of solar absorbers," Energies, vol. 14, no. 21, p. 7140, 2021.

[31] H. Cao, X. Jiang, B. Song, and Y. Shi, "Preparation of tin oxide/ graphene composite for lithium-ion batteries' application," $O P$ Conference Series: Materials Science and Engineering, vol. 474, article 012001, 2019.

[32] K. H. D. Tang, "Climate change in Malaysia: trends, contributors, impacts, mitigation and adaptations," Science of the Total Environment, vol. 650, pp. 1858-1871, 2019.

[33] Meteoblue kuala lumpur, Weather Archive Kuala Lumpur, 2020. 